\title{
The 1996 Intergovernmental Conference and the Prospects of a Non-Discrimination Treaty Article
}

Citation for published version (APA):

Waddington, L. B., \& Bell, M. (1996). The 1996 Intergovernmental Conference and the Prospects of a Non-Discrimination Treaty Article. Industrial Law Journal, 25(4), 320-336.

https://doi.org/10.1093/ilj/25.4.320

Document status and date:

Published: 01/01/1996

DOI:

10.1093/ilj/25.4.320

Document Version:

Publisher's PDF, also known as Version of record

Document license:

Taverne

Please check the document version of this publication:

- A submitted manuscript is the version of the article upon submission and before peer-review. There can be important differences between the submitted version and the official published version of record.

People interested in the research are advised to contact the author for the final version of the publication, or visit the DOI to the publisher's website.

- The final author version and the galley proof are versions of the publication after peer review.

- The final published version features the final layout of the paper including the volume, issue and page numbers.

Link to publication

\footnotetext{
General rights rights.

- You may freely distribute the URL identifying the publication in the public portal. please follow below link for the End User Agreement:

www.umlib.nl/taverne-license

Take down policy

If you believe that this document breaches copyright please contact us at:

repository@maastrichtuniversity.nl

providing details and we will investigate your claim.
}

Copyright and moral rights for the publications made accessible in the public portal are retained by the authors and/or other copyright owners and it is a condition of accessing publications that users recognise and abide by the legal requirements associated with these

- Users may download and print one copy of any publication from the public portal for the purpose of private study or research.

- You may not further distribute the material or use it for any profit-making activity or commercial gain

If the publication is distributed under the terms of Article $25 \mathrm{fa}$ of the Dutch Copyright Act, indicated by the "Taverne" license above, 


\section{EUROPEAN DEVELOPMENTS}

\section{The 1996 Intergovernmental Conference and the Prospects of a Non-Discrimination Treaty Article}

\section{INTRODUCTION}

Preparations for the 1996 Intergovernmental Conference (IGC) have been some of the most elaborate in the history of European integration. In June 1994, at the Corfu summit of the European Council, it was agreed that a 'Reflection Group' should be convened in advance of the IGC to 'examine and elaborate ideas relating to the provisions of the Treaty on European Union' for which a revision is foreseen and other possible improvements (Bull EU 6-1994 'Conclusions of the Presidency' Point 1.25). This group would consist of representatives of the Foreign Ministers of the Member States, the President of the European Commission and two representatives of the European Parliament. Effectively, the Reflection Group Report (sometimes referred to as the Westendorp Report after the chair of the Group, the Spanish Foreign Minister, Carlos Westendorp) has defined the agenda for the IGC.

Of wider interest to labour lawyers will be the fate of the Social Policy Agreement, its full integration into the Treaty of the European Community, its possible modification (e.g. on questions of the extent of qualified majority voting in the Council and of the involvement of the European Parliament) and, of course, the fate of the exclusion of the United Kingdom from its processes and implementation. However, a 'second front' has emerged in these discussions, namely the possibility of a non-discrimination clause at the heart of the Treaty, for example expanding the existing Article $6 \mathrm{EC}$ to include a wide range of discriminatory behaviour:

Within the scope of application of this Treaty, and without prejudice to any special provisions contained therein, any discrimination on grounds of nationality, race, sex, sexual orientation, disability, religion or any other social status shall be prohibited. (Possible amendment in italics).

We have concluded that this would be an ideal opportunity to alert the readership of Industrial Law Journal to the controversies surrounding this proposed amendment. We have therefore invited Mark Bell, graduate of the University of Ulster, now undertaking doctoral studies at the European University Institute into EU policy towards racial and sexual orientation discrimination and Lisa Waddington, Lecturer in Law at the University of Maastricht and author of Disability, Employment and the European Community, (Blackstone, Nomos, et al, 1995) to contribute notes on these respective aspects of antidiscrimination policy. They have been asked to introduce EU policy (or lack of it) in their respective fields, discuss the lobbying activities which have been conducted by relevant pressure groups, outline proposals for reform and their prospects of success. In the light of this last aspect, the fields will be discussed in the order, racial discrimination, disability discrimination and sexual orientation discrimination. 


\section{RACIAL DISCRIMINATION}

\section{A. Racial Discrimination and EU Policy}

A steady trickle of reports of increasing racist violence, combined with evidence of the reemergence of political parties from the extreme right, began to provoke calls for an EC response from the mid-1980s onwards. In particular, the European Parliament was at the forefront of those demanding EC action to combat racial discrimination. The Parliament's consciousness of this problem had been stirred by the results of the 1984 European Parliamentary elections, in which the far right made unprecedented advances. This led it to establish a Committee of Inquiry into the rise of racism and fascism in Europe. The inquiry found that levels of xenophobia in Europe were rising with 'alarming intensity'. (European Parliament (1985) Report of the Committee of Inquiry into the rise of racism and fascism in Europe.) The response of the Community institutions was the 1986 Joint Declaration against Racism and Xenophobia (OJ 1986 C 158/1, signed 11 June 1986). Typical of the Community's record on racial discrimination, it was a measure rich in symbolic value, but lacking substance. The Declaration was signed by the Commission, Parliament and Council, and stressed 'the dangers of racism and xenophobia, and the need to ensure that all acts or forms of discrimination are prevented or curbed'. In the decade since the Joint Declaration, racial discrimination policy has been plagued by prevarication and symbolic politics. This is typified by the 1990 Council Resolution on the fight against racism and xenophobia (OJ 1990 C 157/1, adopted 27 May 1990). The Resolution sets out a variety of policy actions which are recognized as useful in combating racial discrimination. However, it leaves the Member States total discretion as to which of these measures, if any, they choose to adopt, and makes no provision for any means of enforcement.

Inertia in the Council of Ministers has not prevented the Commission from pressing ahead. The Commission has initiated a range of expenditure programmes designed to combat racism and facilitate the better integration of ethnic minority communities. For example, the Cities' Anti-Racism Project, which aims to combat urban racism, commenced in 1995, with an annual budget of ECU 2,000,000 (COM (95) 653, 13.12.95, para 2.2). In December 1995, the Commission produced a Communication on racism, xenophobia and anti-semitism. The Communication outlines the future development of Commission activities in this sphere and presents a proposal (now adopted) for a Council Decision to designate 1997 European Year against Racism (COM (95) 653, 13.12.95).

The Council has also gradually come to recognize the need for an EC response to racism. In June 1994, the European Council agreed to establish a Consultative Commission charged with making 'recommendations, geared to local and national circumstances, on cooperation between governments and the various social players to promote tolerance, understanding and harmony in relations with foreigners' (Bull EU 61994, point I.29). The Consultative Commission began its work in September 1994 and includes representatives of all the Member States and two MEPs. Two years later, that initiative is beginning to bear fruit. Work within the individual Councils of Ministers has resulted in the agreement of two further Council Resolutions concerning racism: Council 
Resolution on the fight against racism and xenophobia in the fields of employment and social affairs (OJ 1995 C 296/13, 5 October 1995); Council Resolution on the response of the educational systems to the problems of racism and xenophobia (OJ 1995 C 312/1, 23 October 1995). On 19 March 1996, the Justice and Home Affairs Council adopted the first Joint Action concerning action to combat racism and xenophobia (OJ 1996 L 185/5). The Joint Action aims to improve coordination between Member States in combating racist material and racist organizations. The Consultative Commission's final report was presented to the European Council at Cannes, in June 1995. Importantly, the report came out clearly in favour of a Treaty amendment to provide the Community with unambiguous powers to act against racism (MEP Glyn Ford: Debates of the European Parliament No 4-462/15, 25.4.95). Whilst there can be no guarantee that any, let alone all, of the recommendations will be accepted, the fact that such a recommendation was made ensured that racial discrimination would be present on the agenda of the 1996 IGC.

\section{B. The history of lobbying on behaff of a non-discrimination clause: racial discrimination}

Lobbying the European Community for more effective action against racial discrimination has become significantly more organized in the $1990 \mathrm{~s}$. This is a development which is in part due to support from the Commission. For example, in 1991, the Commission convened the Migrants' Forum. The Forum contains delegates representing migrant workers, both of EC and non-EC origin, and is a kind of institutionalized pressure group behind greater Community intervention to combat racial discrimination, including support for an appropriate Treaty amendment (Whyte, F L'Europe a visage humain? Paris: L'Harmattan, 1994 at 83).

In 1991, the British Commission for Racial Equality (CRE) tried to clarify the aims of lobbying the Community. The CRE identified three objectives for EC action: Treaty amendment to incorporate racial discrimination, a Directive against racial discrimination and an improvement in the rights of non-EC nationals resident in Community territory. Focusing on the objective of an anti-discrimination Directive, the CRE coalesced with a number of other European groups working to combat racial discrimination (such as the Dutch National Bureau Against Racism) to form the Starting Line group. The group drew up a proposal for a Directive, finally agreed upon in early 1993. The proposal sought to replicate the form a genuine Council Directive would take, thereby presenting the European Commission with a polished proposal, ready for submission to the Council (A. Dummett, 'The Starting Line: A Proposal for a Draft Council Directive Concerning the Elimination of Racial Discrimination', (1994) 20 New Community 530-538).

However, the Commission rejected the proposal, on the basis that the Community lacked the requisite legal competency to enact such a measure; 'the Treaty on European Union does not, at present, provide for Community legal powers in regard to combating racism. [. . .] That, in effect, is why the Commission is not planning at this stage to put forward a Directive to bolster the legal instruments available to Member States to combat racism' (Commissioner Ruberti: Debates of the European Parliament No 4-452/112, 26.10.94). Undeterred, the Starting Line group argued for an amendment to the Treaty which would confer sufficient competency on the Community to enact their draft 
Directive. This proposal became known as the Starting Point. Article 3 of the Treaty sets out the activities with which the Community is charged. The Starting Point proposal would amend Article 3 to add the further objective of 'the elimination of discrimination against persons or groups whether citizens of the European Union or not, on the grounds of race, colour, religion, or national, social or ethnic origin, and the promotion of harmonious relations between such persons or group of persons' (M. Spencer, States of Injustice-a Guide to Human Rights and Civil Liberties in the European Union, London: Pluto Press, 1995; at 136).

The campaign for Treaty amendment has been most effective. The Starting Line is now a coalition of over 250 organizations from all 15 Member States. (Agence Europe No $6761,1.7 .96, \mathrm{p} 4)$. The construction of such a broad coalition in support of the proposed amendment may be significantly attributed to the skillful and focused lobbying techniques employed by the Starting Line group.

\section{Proposals for reform}

This section shall focus on the proposals for reform emanating from the institutions of the Community. In particular, the views of the Parliament, Commission and the Member States shall be examined in greater depth. Whilst other institutions, such as the Court and the Committee of the Regions, have issued their own opinions on the IGC they have not concerned themselves with the question of an anti-discrimination clause.

\section{(i) The European Parliament}

The Parliament has long espoused the idea that the Treaty should be amended to incorporate racial discrimination. The 1985 Report of the Committee of Inquiry into the rise of racism and fascism in Europe concluded, inter alia, that it might be necessary to amend the Treaty on the issue of racial discrimination (European Parliament, 1985, 105). The Parliament's 1995 Resolution on the IGC, paragraph 7 called for 'an explicit reference in the Treaty to the principle of equal treatment irrespective of race, sex, age, handicap or religion' (OJ $1995 \mathrm{C}$ 151/56, 17.5.95). Its 1996 Resolution on the IGC emphasizes that there must be more than a merely passive commitment to nondiscrimination. Instead there should be 'a clear obligation on the part of the Union to develop a policy to overcome social injustice, exclusion, discrimination . . .' (OJ 1996 C $96 / 77,13.3 .96)$. However, the Parliament remains divided over proposals for changes to the status of non-EC nationals permanently resident within the Community. The explanatory statement on the 1996 Resolution states that 'any declarations opposing racism or xenophobia will be diluted if the actual legal position of their country citizens remains ambiguous'. Nonetheless, the same report also argues 'it would clearly be unrealistic to seek to include a provision specifically dealing with the political rights of third country nationals' (Dury/Maij-Weggen report; European Parliament document A4-0068/96/B, 5.3.96, pages 8 and 13). The final Resolution is a rather uneasy compromise between the two strains of opinion on this issue. Paragraph $4(16)$ does contain a call for non-EC nationals to be extended 'the right to vote in local elections', but 
refrains from endorsing the extension of European citizenship to these individuals (OJ 1996 C 96/77, 13.3.96).

\section{(ii) The European Commission}

The Commission first raised the question of Treaty amendment in the 1994 White Paper, European Social Policy - a Way Forward for the Union. This acknowledged that 'serious consideration must be given to the introduction of a specific reference to combating discrimination on the grounds of race, religion, age and disability'. (COM (94) 333, p 40.) This position was consolidated in the Commission's 1995 Report on the operation of the Treaty on European Union. It laments the fact that 'citizens of the Union have, at this stage, no fundamental text which they can invoke as a summary of their rights and duties. The Commission thinks this gap should be filled, more especially since such an instrument would constitute a powerful means of promoting equal opportunities and combating racism' (SEC (95) 731, 10 May 1995; at $p$ 1c). The Commission's position is laid out with more precision in the Communication on racism, xenophobia and anti-semitism, from December 1995. The Commission identifies a number of alternative methods to guarantee non-discrimination in EC law, but concludes a 'general non-discrimination clause in the Treaty, which would then apply automatically to all Community acts' would be 'the simplest solution, and the one the Commission would prefer' (COM (95) 653, $13.12 .95, \mathrm{p} \mathrm{18}$ ). This stance was reiterated in their 1996 submission to the IGC (Reinforcing Political Union and Preparing for Enlargement: (COM (96) 90, 28.2.96; $\mathrm{p}$ 3).

\section{(iii) The Member States}

The support for a Treaty amendment from the Consultative Commission, a committee of representatives of the Member States set up in 1994 to review EU policy towards racism and xenophobia, gave an indication that many of the Member States accepted the need to incorporate racial discrimination into the Treaty. This was reinforced in the report of the Reflection Group which indicated strong support for a proclamation of such European values as 'equality between men and women, non-discrimination on grounds of race, religion, sexual orientation, age or disability' (Council-EU (1995) Reflection Group report and other references for documentary purposes, para 22). Not only does it record 'majority support' for inserting 'a general clause prohibiting discrimination on grounds of gender, race, religion, age disability or sexual orientation' but there was also support for an 'express condemnation in the Treaty of racism and xenophobia'. The report points out that whilst there may be majority support for such an amendment, there is not unanimity. 'One member, however, felt that new or increased Community references in these sensitive areas were unnecessary, and that such rights were best secured in the national context (ibid, para 39). The identity of this member is not hard to discern. In its White Paper on the IGC, A Partnership of Nations, the UK government squarely states its belief that 'problems of discrimination (particularly on such sensitive questions of race and religion) are best dealt with . . through national legislation' (Foreign and Commonwealth Office, 1996, para 57). 
The Member States are even more divided on the issue of the legal status of non-EU nationals. Paragraph 55 of the Reflection Group report states 'some members . . . would like to see the Union introduce a common status for legally resident third-country nationals, whilst others point out that this would require the precondition of an overall common immigration policy'. The absence of consensus on improvements to the legal status of non-EU nationals, even within the Parliament, forces one to conclude that it is improbable that progress will be made on this issue at the forthcoming IGC.

\section{(iv) Prospects for success}

Wide-ranging support exists for an amendment of the Treaty to enhance the Community's commitment to combating racism. Support for such a change may be found throughout the various institutions of the Community. The Parliament, Economic and Social Committee and the Commission have all given public backing to such an amendment. Perhaps more importantly, the greater number of the governments of the Member States have endorsed the need for a 'racial discrimination' amendment.

Also important has been the commitment to promoting racial discrimination policy by a succession of Presidencies of the European Council. The Spanish Presidency, in the second half of 1995, and the Italian Presidency, in the first six months of 1996, both demonstrated a determination to push racial discrimination policy forward. Both Presidencies also had important roles to play in the run-up to the IGC; the Spanish had the Chair of the Reflection Group and the Italian Presidency was responsible for the convening the IGC at the end of March 1996. Indeed, at the first meeting of the representatives of the Foreign Ministers for the IGC negotiations, on 1 April, the Italian Presidency was reported to have presented five 'files' for discussion, one on an antidiscrimination clause (Agence Europe No 6701; 3.4.96, p 2). Further ministerial meetings on the IGC have continued to consider the issue. At their meeting on 21-22 May, it was reported that the ministers 'referred to the scope for extending the principle of nondiscrimination on the grounds of race, sex, religion, beliefs and opinions or even disablement' (European Report No 2134 Section I, p 1, 25.5.96).

The problem remains though of opposition from the UK, and other less visible sceptics, to any such amendment. The political realities of the IGC dictate that some compromises must be made as part of the overall bargaining process. This being the case, it may be that this is one issue where the UK would find it relatively painless to defer to their European counterparts. The uncompromising tone of the UK's stance belies evidence of a considerably more pragmatic position. Under political pressure from the other Member States, the UK government reversed an earlier veto on a Joint Action against racism in March 1996, and in July approved a Council Decision to make 1997 European Year Against Racism. Thus, it is not the case that the UK government is implacably opposed to any EU intervention in this sphere, rather it appears willing to show a certain amount of flexibility in return for appropriate concessions. Indeed, given the degree of political momentum behind an anti-discrimination amendment, it seems fair to conclude that the main question now surrounds the nature of the final amendment, rather than whether or not there should be any such amendment. Indeed, it is here where the sceptics could yet 
deprive the amendment of the potential it holds. For example, one can well imagine the UK government will seek to shift any such amendment into the Agreement on Social Policy, and thus prevent it from having any direct domestic implications for Britain. A more probable scenario is that the Member States would decide not to amend the EC Treaty, but simply to add racism to Title VI of the Treaty on European Union, which provides for cooperation on justice and home affairs. This would give the Member States some symbol of progress, whilst still not taking the crucial step of extending EC competency to combat racism. It would keep racial discrimination policy on a fragile footing-dependent on unanimity for progress, and beyond the scrutiny of the Court of Justice. Given that the Justice and Home Affairs Council has already demonstrated itself capable of adopting Joint Actions on racism on the basis of the existing provisions of Title VI, amendment of Title VI alone would not represent a significant breakthrough.

Despite these words of caution, the overall picture remains favourable. If the Treaty is amended, the challenge will then be for the Community to follow through on its commitments. Treaty amendment in itself is of little worth if there is not a preparedness to see it as only a precursor to further action. In the words of MEP Claudia Roth, (Debates of the European Parliament No 4-452/115, 26.10.94).

What we need here and now is not the same old repeated solemn declarations, because all verbal condemnations are pointless as long as policies remain the same.

\section{DISABILTY DISCRIMINATION}

\section{A. Disability Discrimination and the European Union}

The lack of reference to disability in the present Treaty on European Union has restricted the Community's ability to initiate programmes and policies directed at disabled people. The Community has made use of Article $128 \mathrm{EEC}$ and $235 \mathrm{EC}$ to launch a series of limited action programmes, providing for information and exchange activities, and focusing on employment, education/training and independent living. The two most recent programmes go under the name of Helios (Handicapped People in the European Community Living Independently in an Open Society). The present Helios Programme expires at the end of 1996. Given the present reluctance of the German government to support any new social programmes based on Article $235 \mathrm{EC}$, the Commission has decided not to propose a new multi-annual programme. Needless to say, the inclusion of a disability non-discrimination clause in the Treaty would considerably enlarge the Commission's scope for proposing such social programmes. The Community also provides funding for programmes through the European Social Fund, including the Horizon fund which is now aimed exclusively at projects involving disabled people; supports research into technology aimed at benefiting disabled and elderly people through TIDE (Technology Initiative for Disabled and Elderly people); and has adopted a policy instrument on the employment of disabled people (Council Recommendation and Guideline on the Employment of Disabled People in the European Community of $24 \mathrm{July}$ 1986, OJ L225/43, 12.8.86. For further information on this, and other initiatives, see 
Waddington, Disability, Employment and the European Community, Blackstone, Nomos, et al, 1995). However the employment recommendation received little attention and the benefits of the activities and programmes have been largely confined to those who participated therein.

The absence of a reference to disability in the Treaties has not only limited the Communities' ability to introduce measures aimed at disabled people, it has also resulted in a frequent failure to consider the position of disabled people when producing more general legislation and policy. The result has been proposals for legislation, and adopted legislation, which indirectly discriminate against certain groups of disabled people. For example, the 1991 directive on the mutual recognition of telecommunication terminal equipment sets certain minimum standards which must be met by producers of such equipment in order to achieve free circulation within the European Union (Directive of 29 April 1991 on the approximation of the laws of the Member States concerning telecommunications equipment, including the mutual recognition of their conformity ( $91 /$ 263/EEC), OJ L128/1, 23.5.91 Article 4). These standards do not include the requirement that the equipment be accessible for use by people with a visual impairment, and the result has been to undermine national legislation, such as that in the United Kingdom, which does include this requirement. Numerous other proposals for (single market harmonization) legislation have also failed to take the (access) needs of disabled people into account; the lifts Directive (Directive 95/16/EC of 29 June 1995 on the approximation of the laws of Member States relating to lifts. OJ L213/1, 7.9.95. Disability access now is included by virtue of Annex i, Article 3 1.2) and the draft of the buses and coaches Directive (Draft Directive on Bus and Coach Type Approval, III/4076/90-en Rev 6) did not initially require that new lifts and buses be accessible to people who use a wheel chair, or who have certain other disabilities, wherever possible. It was only comprehensive campaigning by disability Non Governmental Organizations (NGOs) and members of the European Parliament which rectified this situation. Furthermore, free movement legislation rarely takes account of the fact that disability can impose additional barriers on those who wish to take up employment, set up in business, study in or simply move to another Member State. The result of this invisibility of disabled EU citizens in the Treaties has been a package of Community legislation which, on the whole, ignores disabled people, and in so doing, helps to perpetuate the disadvantage which they already labour under.

\section{B. The history of lobbying on behalf of a non-discrimination clause: disability discrimination}

Calls for such a Treaty amendment date back to 1993 and beyond, and have been focused around the annual European Day of Disabled Persons. This is an event organized by European Disability NGOs, and funded by the Commission and the European Parliament. Members of the Disability Forum, a consultative body established within the framework of the Helios programme and made up of European NGOs, each addressing a particular kind of disability, e.g. learning disability, visual disability, or particular activity, e.g. mobility, education, and National Disability Councils, are invited to make proposals for organizing the event. The first European Day (1993) was organized by 
Disabled People's International, an organization of predominantly physically disabled people. In that year the European Disabled People's Parliament, held to mark the occasion, passed a resolution calling for, amongst others 'a general anti-discrimination' clause to be included in the Treaty. The most recent European Days (1995 and 1996) have been organized by a consortium of three European NGOs: the International League of Societies for Persons with a Mental Handicap-European Association, the World Federation on Mental Health-European Region Committee, and Autism Europe. To mark the 1995 European Day a report entitled 'Invisible Citizens' was presented to the European Parliament and Commission, which revealed the extent to which disabled people are ignored and discriminated against in Community law and policy, and which contained a proposal for the inclusion of a non-discrimination clause in the Treaty based on the present Article 6 (Disabled Persons Status in the European Treaties, Invisible Citizens. Report prepared for the European Day of Disabled Persons, 7 December 1995, p 109/110):

Within the scope of application of this Treaty, and without prejudice to any special provisions contained therein, any discrimination on grounds of nationality, race, sex, sexual orientation, disability, religion or any other social status shall be prohibited.

For the purposes of this Treaty, discrimination may be defined as including any distinction, exclusion, restriction or preference or denial of reasonable accommodation, enjoyment or exercise of the rights of EU citizens.

For the purposes of this Treaty, the principle of equal rights implies that the needs of each and every individual are of equal importance, that those needs must be made the basis for the planning of societies, and that all resources must be employed in such a way as to ensure that every individual has equal opportunity for participation.

This article shall be without prejudice to measures designed to benefit disabled people.

Reasonable accommodation is the process whereby the needs of disabled people are accommodated, e.g. the provision of a ramp to allow a person who uses a wheel chair access to a building. Reasonable accommodation can take many different forms and apply in many different areas. Existing national disability anti-discrimination legislation, e.g. the Americans with Disabilities Act and the British Disability Discrimination Act, accept that the denial of a reasonable accommodation (or a reasonable adjustment in the case of the British Act) amounts to disability discrimination.

This proposal is now being lobbied on by disabled people throughout Europe. As part of the 1996 European Day of Disabled Persons a group of lawyers and economists have been commissioned to prepare a report to respond to the points raised in the Reflection Group Report, and, in particular, the concerns regarding the legal and economic consequences of a disability non-discrimination clause (see below).

\section{Proposals for reform}

One senses that a new attitude is developing towards disability in the Community institutions, and that there is increased awareness of the issue of disability discrimination, 
and of the inability of the Community to act in this area under the present Treaty. This follows an international trend, whereby other international organizations (see for example, the United Nations document, The Standard Rules on the Equalization of Opportunities for Persons with Disabilities 1994, New York, United Nations) and nations have taken action to combat disability discrimination and promote equality of opportunity. The most obvious example of a country which has legislated to combat disability discrimination is the United States where the Americans with Disabilities Act was adopted in 1990 (Pub L 101-336, 104 Stat Codified at 42 USCA $\$ \$ 12101-12213$ ). However, other non-European countries (e.g. Canada, Australia) and European countries (United Kingdom, Ireland, France, Germany), have also adopted, or are in the process of adopting, disability non-discrimination laws.

The new focus on disability discrimination within the European Union has occurred partly as a result of the Commission's recent review of Community social policy. In response to the 1993 Green Paper on social policy (European Social Policy-Options for the Union, A Green Paper COM (93) 551), the Commission received numerous comments, many of which dealt with disability. The European Parliament, the Economic and Social Committee and many NGOs, including the European Trade Union Confederation, and disability NGOs, called upon the Commission to initiate action to combat disability discrimination. The Commission supported this call in the White Paper which it subsequently published (A White Paper: European Social Policy-A Way Forward for the Union COM (94) 33). The Commission felt, however, that there existed no suitable Treaty article on which it could base a proposal for a binding antidiscrimination instrument, and therefore stated in the White Paper that:

at the next opportunity to revise the Treaties, serious consideration must be given to the introduction of a specific reference to combatting discrimination on the grounds of ... disability.

Subsequently both the Commission and the European Parliament presented submissions to the Reflection Group calling for the inclusion of a non-discrimination clause which makes specific reference to, amongst others, disability. However, a later Commission Opinion on the IGC only makes reference to the inclusion of a general antidiscrimination clause, with no specific reference to disability (Reinforcing political union and preparing for enlargement (COM (96)0090-C4-0151/96, (para 9, Chapter 1):

The Conference should also incorporate in the Treaty provisions banning discrimination of any kind-particularly on the basis of sex, thereby extending the provisions on equal pay-and condemning racism and xenophobia.

The European Parliament has reiterated its demand in a Resolution on the convening of the Intergovernmental Conference (A4-0068/96, Article 4.5):

The European Union should include in this special chapter [on citizenship] the principle of equal treatment and non-discrimination regardless, in particular, of race, gender, sexual orientation, age, religion or handicap (emphasis added). 
Representatives of the disability movement also met with the chair of the Reflection Group, Carlos Westendorp, to argue their case. When the Reflection Group published its report at the beginning of December 1995 it became clear that the vast majority of Member States favoured amending the Treaty so as to include a non-discrimination clause, as indicated above, to include disability. In particular,

Special consideration for disabled people both by referring to them in the nondiscrimination clause in Article 6 of the TEU and by a clause in one of its chapters [italics added]' received majority support. However, with regard to the latter proposal (provision in one of the Treaty chapters) 'some [Member States] feel that a safeguard clause should be provided making it possible to limit any disproportionate economic consequences which might derive from such a provision'.

It is clear from the Reflection Group Report that all but one of the Member States have accepted that there is a need to take action to combat discrimination affecting disabled people (and other groups) at the European level. However, according to the report, this is subject to a 'more detailed assessment of their legal and economic implications by the Conference'. The odd one out is, almost inevitably, the United Kingdom-but the subsequent reticence of Member States to publicly commit themselves to a disability nondiscrimination clause show that it is not alone in having concerns.

\section{Prospects of success}

Thus far only the United Kingdom has made its opposition to a (disability) nondiscrimination clause clear. (The White Paper on the IGC published by the British government in March 1996 contains the following statement: 'It [the British government] does not consider, however, that the European Union is the right context for the protection of fundamental rights, or for a general clause, as some partners have advocated, prohibiting discrimination for example on grounds of gender, sexual orientation, race, religion, age, or disability' (emphasis added) ( $A$ Partnership of Nations-The British Approach to the European Union 1996 IGC, para 55). On the other hand, only Ireland and Greece have committed themselves to supporting the inclusion of such a clause. (The Irish government's White Paper on the IGC published in March 1996 contains the following statement: 'The issue of a non-discrimination clause, covering such matters as disability, is likely to be considered by the IGC. The implication of such a clause will be examined at European and national level. The Government will seek to identify Treaty amendments in this area, with a view to initiating a Treaty change in the course of the IGC. The purpose of such a Treaty change would be to reflect in an appropriate way the rights and needs of people with a disability' (White Paper on Foreign Policy: Challenges and Opportunities Abroad Para 3.209).

This is confirmed by a note produced by MEPs Brok and Guigou (the two parliamentary members who have observer status at IGC meetings) for fellow parliamentarians (Note of 5 June 1996, RC/rm-IGCsummeps, Section 3):

A majority [of Member State representatives] supported the inclusion in the Treaty of 
strengthened provisions on gender equality and combatting racism and xenophobia, but only a minority at present support a reference to non-discrimination on grounds of handicap, age or sexual orientation.

The fact that Ireland supports the inclusion of a disability non-discrimination clause in the Treaty is not insignificant in that this Member State presently holds the Presidency of the Union, and will play a major part in drafting the first version of the new Treaty; however this level of support is clearly insufficient if a disability non-discrimination clause is ultimately to be included in the Treaty. The remainder of the Member States seem to be largely sympathetic to the claim that a disability non-discrimination clause should be included in the Treaty, but remain concerned as to the consequences. Some, such as Denmark, are rightly proud of their national policy and legislation, and are reluctant to approve any amendment which they perceive as undermining their existing achievements. Others may simply fear excessive costs.

Meanwhile the disability movement is trying to emphasize that any clause should primarily address Community legislation and policy making, and ensure that disabled people's needs are taken into account when action is taken at the Community level, and therefore have limited impact at the national level. It seems they have a long struggle ahead of them.

\section{SEXUAL ORIENTATION DISCRIMINATION}

\section{A. Sexual orientation discrimination and the EU}

Discrimination against gay men and lesbians is not an issue which has been traditionally associated with the European Community, but the signs are that this may be beginning to change, albeit with some hesitancy. The issue was first raised by the European Parliament, in the 1984 report on Sexual Discrimination at the Workplace (Squarcialupi: European Parliament Document No 1-1358/83). This inspired the Parliament to pass a Resolution calling on the Commission to 'submit proposals to ensure that no cases arise in the Member States of discrimination against homosexuals with regard to access to employment and dismissals' (Para 5b, OJ 1984 C 104/46; 13.3.84). Whilst the Commission acknowledged 'it is unacceptable that homosexuals should be refused employment or suffer victimization and harassment at work, . . . as a matter of practical politics' they felt there was little point in proceeding, because any proposed legislation on the subject would not meet with the approval of the Council (Commissioner Ivor Richard Debates of the European Parliament No 1-311/17, 13.2.84).

The Commission's position has continued to fluctuate between what it feels to be 'right' and what it perceives to be 'realistic'. At different times, and on different issues, the Commission has felt able to intervene to combat sexual orientation discrimination. For example, during the tenure of the Social Affairs Commissioner Vasso Papandreou, the Commission commenced an informal dialogue with gay and lesbian groups, culminating in a meeting with Commissioner Papandreou in December 1990 (P. Tatchell, Europe in the Pink-Lesbian and Gay Equality in the New Europe London: GMP Publishers, 1992; p 22). This proved instrumental in achieving the first significant breakthrough for 
campaigners, in the shape of the 1991 Commission Recommendation on the Protection of the Dignity of Women and Men at Work (OJ 1992 49/1, 27.11.91). Annexed to the Recommendation is a Code of Practice on measures to combat sexual harassment. The introduction includes the short, but significant sentence 'it is undeniable that harassment on grounds of sexual orientation undermines the dignity at work of those affected and it is impossible to regard such harassment as appropriate workplace behaviour'.

Despite these signs of support, progress has continued to be rather haphazard. In 1994, Commissioner Bruce Millan presented a positive appraisal of the Commission's stance to the European Parliament. Responding to a Parliamentary report which once again highlighted the discrimination encountered by lesbians and gay men (Report on equal rights for homosexuals and lesbians in the European Community European Parliament Document A3-0028/94), the Commissioner accepted that 'this form of discrimination should be expressly forbidden in Community law, and the Commission will in future draft anti-discrimination clauses accordingly in the areas for which we have competence (Debates of the European Parliament No 3-442/44, 7.2.94). This policy appears to have finally begun to manifest itself in the last six months. In a crucial precedent, the Council Directive on the framework agreement on parental leave concluded by the social partners, adopted on 29 March 1996, includes a statement in the preamble providing that there shall be no discrimination 'based on race, sex, sexual orientation, colour, religion or nationality' in the implementation of the Directive (European Report No 2120 Section IV, $\mathrm{p} 19,30.3 .96)$. This approach seemingly holds the potential for an evolving principle of non-discrimination in Community law, which includes sexual orientation.

Despite these positive initiatives emanating from within the Commission, progress remains constantly constrained by the absence of any reference to sexual orientation in the EC Treaty. The Commission has explained its failure to progress to legislation prohibiting sexual orientation discrimination by reference to the limits imposed upon them by the Treaty. 'The Commission has competency over equal treatment for men and women and nationality discrimination', but 'the Community has no power to intervene where other types of discrimination are concerned, notably those affecting sexual orientation' (van den Broek: OJ 1995 C 326/40, in answer to a written question from MEP Luciano Vecchi).

\section{B. The history of lobbying on behaff of an anti-discrimination clause: sexual orientation}

The international campaign for equal treatment for gay men and lesbians has been spearheaded by the International Lesbian and Gay Association (ILGA). The ILGA was formed in 1978 and is a federation of various gay and lesbian groups from across the world. The organization now has more than 300 member groups, including 90 groups from within the European Union. Nonetheless, organized cross-border lobbying of the EU is a relatively recent phenomenon. Indeed, it was only in 1990 that the ILGA formed a Working Group to specifically address lobbying the European Community. This was created at the initiative of the British Group, Stonewall, and includes groups from a number of Member States, such as the Gay and Lesbian Equality Network (GLEN) based in Ireland ('Profile: Tim Barnett' (1991) 39 Equal Opportunities Review 31). 
The work of the ILGA is complemented by that of Egalite. Whereas the ILGA is interested in changing EC law and policy, to enhance the position of gay and lesbians throughout the Community, Egalite is concerned with the internal affairs of the Community-namely; the terms and conditions of the employees of the various EC institutions. Also at work is the International Lesbian and Gay Youth Organization (ILGYO). The ILGYO was formally established in 1986 and has been particularly active in raising gay and lesbian concerns in the EC Youth Forum. It may be no coincidence that the Youth Forum recently recommended that the Treaty be amended to ban any form of discrimination (Agence Europe No 6698, 29.3.96, p 4).

In its approach to the IGC, the ILGA has chosen to focus on one specific change-an anti-discrimination amendment. This seems to be a wise strategy-allowing the ILGA to capitalize on the pre-existing support for a general anti-discrimination clause. It is easier to argue for inclusion in some global measure, than to campaign for changes which would only be of benefit (and interest) to gays and lesbians. The ILGA has also sought to emphasize that it would be insufficient for the EU to accede to the European Convention on Human Rights. At the European Parliament's public hearings on the IGC, Inge Wallaert, the Secretary-General of the ILGA, stressed that the ILGA 'will not be satisfied simply with the European Union's endorsement of the European Convention on Human Rights as this convention does not yet include sexual orientation' (European Parliament Document A4-0068/96/Part C.1; 7.3.96, p 9).

The achievement of an anti-discrimination amendment is being pursued by a combination of national and European-level lobbying. The ILGA has recommended that 'all of Europe's gay organisations should press their countries' representatives at the IGC (by whatever means they deem appropriate)' (Andy Quan (Coordinator ILGA) to all EU ILGA member groups, March 1996 (internal correspondence)). This wisely allows for lobbying to be tailored to national circumstances. For example, in Denmark, the gay and lesbian rights group, LBL, chose to focus on lobbying the Foreign Minister, who agreed to consider supporting the inclusion of sexual orientation in an anti-discrimination clause (S. Jensen, Euroletter No 39; February 1996 (published on behalf of ILGA)). The two tiers of lobbying have been integrated through circulating a statement for the signature of all member groups. This will then be available for use by both national groups in their campaigns and the ILGA in its European-level lobbying. The statement sums up the position of the ILGA concerning the IGC (statement agreed by European Regional meeting of ILGA, Riga (Latvia), December 1995):

The European gay and lesbian organisations that have signed this statement demand that the follow-up treaty to the Maastricht Treaty on European Union includes an antidiscrimination clause covering sexual orientation ... We consider an anti-discrimination clause to be a precondition for further steps to establish equal treatment of all European Union citizens.

\section{Proposals for reform}

This section shall focus on the proposals for reform which have emanated from the institutions of the European Community. 


\section{(i) The European Parliament}

The Parliament has consistently been the one institution to which gay men and lesbians could look to for a sympathetic hearing. It is unsurprising then that the Parliament has explicitly endorsed calls for the inclusion of sexual orientation in an anti-discrimination amendment. In 1994, a Parliament Resolution declared: 'the EC Treaties must make stronger provision for the defence of human rights, and therefore calls on the Community institutions to make preparations, in the context of the institutional reform scheduled for 1996, for setting up a European institution able to ensure equal treatment, without reference to nationality, religious faith, colour, sex, sexual orientation or other differences' (OJ 1994 C 61/40, 8.2.94). Despite the sentiment expressed above, sexual orientation nearly failed to get mentioned in the Parliament's 1995 Resolution on the IGC. There was no mention of sexual orientation in any of the Parliamentary Committee's reports, or the draft Resolution. However, paragraph 7 of the Resolution was subsequently amended to state 'the Treaty should contain a clear rejection of racism, xenophobia, sexism, discrimination on grounds of a person's sexual orientation . . . (OJ 1995 C 151/56, 17.5.96). Whilst this ensured the issue was presented to the Reflection Group, it demonstrates that even within the Parliament the issue only enjoys rather fragile support.

The omissions made in the 1995 proceedings were not repeated in the Parliament's 1996 submissions to the IGC. The explanatory statement on the 1996 Resolution recognizes the failure of the 1995 Resolution to accord equal status to sexual orientation and sets out to ensure that this is not repeated (Dury/Maij-Weggen report; European Parliament Document A4-0068/96/B, 5.3.96, p 6). There was also express support from a number of Parliamentary Committees, such as the Committee on Women's Rights (European Parliament Document A4-0068/96/ANN; 5.3.96). This augmentation in support from within the Parliament is reflected in the final Resolution which calls for a chapter on fundamental rights to be entered in the Treaty. This should include 'the principle of non-discrimination regardless, in particular, of race, gender, sexual orientation, age, religion or handicap' (OJ 1996 C 96/77, 13.3.96).

\section{(ii) The European Commission}

The Commission has been supporting an improvement in the Community's commitment to human rights for some time. In particular, the White Paper European Social Policy-A Way Forward for the Union acknowledged that the Union must act to provide a guarantee for all people against the fear of discrimination if it is to make a reality of free movement within the single market' (COM (94) 333, p 40). This sentiment was echoed in its 1996 submission to the IGC Reinforcing political union and preparing for enlargement: the Conference should also incorporate in the Treaty provisions banning discrimination of any kind' (COM (96) 90, 28.2.96; p 3). However, despite general commitments to nondiscrimination, the Commission has never specified that an anti-discrimination amendment should include sexual orientation. Whilst this could be implied from the statements quoted above, there remains a shadow of doubt. The doubt over the exact terms of the 
Commission's position is increased by the fact that the Commission has specified that the amendment should refer to age. race, religion and disability (see: White Paper on European Social Policy). To mention some groups, but not others, suggests that sexual orientation is not a priority issue for the Commission.

\section{(iii) The Member States}

The Member States have also adopted a rather non-committal attitude to sexual orientation discrimination. As indicated above, the Reflection Group report sets out a desire to proclaim European values including non-discrimination on grounds of sexual orientation but subject to the reservation of one Member State. The report reveals that there exists broad support for an anti-discrimination clause. It does not tell us though what specific support exists for the inclusion of sexual orientation within that antidiscrimination clause. No doubt exists as to the objections of the UK government to any such amendment. Its White Paper, A Parnership of Nations, states that the UK government "does not consider, however, that the European Union is the right context for the protection of fundamental rights or for a general clause, as some partners have advocated, prohibiting discrimination for example on grounds of gender, sexual orientation, race, religion, age or disability' (Foreign and Commonwealth Office, 1996, para 55).

\section{(iv) Prospects of success}

The outright opposition of some Member States, and the malign indifference of others, could justifiably cause one to be pessimistic about the prospects for the inclusion of sexual orientation in a general anti-discrimination clause. However, many groups have a vested interest in an anti-discrimination amendment, and, as the Reflection Group report reveals, there are many Member States' governments who are supporting this proposal. Importantly, the Irish government, who hold the Presidency of the EU for the second half of 1996, and will chair the IGC negotiations during this period, have indicated their support for an anti-discrimination amendment. The Irish Minister for Equality and Law Reform, Mervyn Taylor TD, has stated that 'Ireland will favour exploring clear and specific provisions on discrimination on grounds such as gender, race and disability' (Irish Times, 'Taylor wants EU treaties to include equality provision', 14 May 1996) (emphasis added). Whilst an anti-discrimiantion provision is clearly prominent on the IGC agenda, the obvious risk for sexual orientation campaigners is that somewhere in the negotiations 'sexual orientation' may get deleted from the proposed amendment.

The ILGA certainly recognize that this is the challenge that they are up against. They have exhorted their members to lobby the EU governments 'to see that the proposed non-discrimination clause remains intact until the very last stage of the negotiations' (Andy Quan (Coordinator ILGA) to all EU ILGA member groups, March 1996 (internal correspondence). One of the greatest risks is that agreement will be reached on an antidiscrimination amendment, but only following concessions to the less supportive Member States. It is at this stage that reference to sexual orientation could potentially be removed. 
For example, there would be little real difficulty for the UK government to accept the principle of non-discrimination on grounds of race, sex and disability. However, it would have genuine difficulty in accepting the principle of equality for gay men and lesbians. Given that it is the same government which has fought court cases to defend its right to exclude gays and lesbians from the armed forces, it is unlikely to look favourably upon a proposal to enshrine homosexual equality in the EC Treaty, especially given the inevitable reaction this would produce from right-wing Eurosceptics.

Evidence is already emerging of the kind of opposition that exists to include 'sexual orientation' in the Treaty. Egalite reported in May a warning from Dutch MEP Peter Pex that 'in the discussion papers of the Council on the IGC, the words 'sexual orientation' and 'sexual preference' had been removed' (Egalite Newsletter Vol 14, p 2; May/June 1996). This has been attributed to the actions of the Italian government which held office prior to the Italian general election of 21 April 1996 ('Dropping of gay rights in new EU treaty is questioned by Irish government' Gay Community News June 1996, p 1, Dublin: NLGF). This illustrates the fragility of the whole negotiation process. The ILGA's strategy is to ensure 'sexual orientation' remains in the draft as long as possible. This is with a specific development in mind-the commencement of the Dutch Presidency in January 1997. Their hope is that the relative strength of Dutch gays and lesbians will make it politically impossible for the Dutch government to preside over the deletion of 'sexual orientation' from the draft Treaty. This strategy recently received a major boost when the Irish negotiator, Noel Dorr, declared the Irish Presidency would submit a paper in September which would seek to have sexual orientation included in the Treaty ('Irish government seeks to have gay rights included in new European Treaty' Gay Community News, September 1996, p 1). However, it is telling that there is little other evidence of any government unequivocally declaring public backing for the inclusion of sexual orientation in the Treaty. Without a broader base of support than the Irish proposal and the hopes for the Dutch Presidency, it seems the ILGA will be fighting an up-hill struggle.

MARK BELL

European University Institute, Florence

\section{LISA WADDINGTON}

Lecturer in European Community Law, University of Maastricht (NL) and European Observer to the International League of Societies for Persons with a Mental Handicap-European Association. The author is grateful to Aart Hendriks who commented on an earlier version of her contribution. 